\title{
Vigna lanceolata in the fire-stick farming and the Australian Aboriginal culture
}

\author{
Alfredo Castelli' · Aleksandar Mikić ${ }^{2}$
}

'Sergio Bonelli Editore, Milan, Italy

${ }^{2}$ Novi Sad, Serbia

\begin{abstract}
Summary: An amphicarpic and tuberous legume yam Vigna lanceolata Benth., endemic to Australia, has had an extraordinary significance in the peculiar type of farming and entire culture of the Aboriginal peoples for tens of millennia. Our review, welding plant and human sciences, offers a concise and informative presentation of the species, by elaborating its taxonomy and morphology, describing its beneficial nutritional and medicinal properties, exploring its ecogeography, with a remarkable population abundance in the northern areas of the continent, assessing its extensive spreading as a consequence of the past fire-use environmental changes and ways of its wilderness reconnaissance, harvest and food preparation, depicting its role in the Australian Aboriginal art, as one of the most sacred objects in the Dreamtime religion, presenting its vernacular names in 85 extinct and living Australian Aboriginal languages and concluding with opening new horizons of its research, through recently established biodiversity and breeding programmes.

Key words: Aborigine, art, Australia, fire-stick farming, Vigna lancelata
\end{abstract}

Supplementary materials:

Supplementary File 1: https://doi.org/10.6084/m9. figshare.8145935.v2

Supplementary File 2: https://doi.org/10.6084/m9.figshare.8145800.v2

\section{The Children of the Dream}

According to the prevailing theory of the recent African origin of modern humans (Homo sapiens sapiens), probably the first and the most important out-of-Africa migration started around 70,000 years ago, when the ancestors of the present Aboriginal Australians,

\section{Corresponding author}

aleksandar.mikich@gmail.com

Acknowledgements:

The authors appreciate most respectfully the assistance from the esteemed elders of the Miriwoong people with Ms. Maryann of the Yawuru people, Dr. Amanda Lissarague, Ms. Clarrie Kemarr Long, Dr. Frances Kofod, Dr. Knut J. Olawsky and Dr. Jane Simpson in obtaining hardly accessible information about the names in various Australian Aboriginal languages, dialects and speeches, most of which are gravely endangered or on an inevitable way to perish forever. The authors are also cordially grateful to the following persons and institutions for their kindness in providing some of the segments of the figures and the video presented in this review: Mr. Ludo Kuipers, Mr. Russell Cumming, Mr. Maximilian Dörbecker, Mr. Mick Erglis, Mr. Jean-Paul Ferrero, Mr. Made Harimbawa, Ms. Monique Larrey, Mr. Adam Peterson, the Batchelor Institute of Indigenous Tertiary Education, the Cooee Art Gallery and the National Museum of Australia.

Cite this article:

Castelli A. \& Mikic A. (2019). Vigna lanceolata in the fire-stick farming and the Australian Aboriginal culture. Ratar. Pont:, 56 (2), 56-64.
Papuans and several other contemporary peoples of South Asia and Oceania took the Southern Dispersal Route, crossing the Red Sea, travelling along the Indian Ocean coast and, via Sundaland and Wallacea, ultimately settled in Sahul, a landmass merging New Guinea, Australia, Tasmania and adjacent islands, at least 65,000 years ago (Bae et al., 2017; Castelli \& Di Cesare, 1996; Mikić, 2011; O’Connell et al. 2018; Suppl. File 1, Fig. 1).

Although having commenced much later in comparison to the anthropological studies of diverse civilisations in other continents, those of the Australian Aboriginal culture are continuously revealing an extraordinarily ancient society with colossal knowledge on and skill in art, astronomy, biology, ecology, ethnobotany, history, law, linguistics, mathematics and recreational games (Castelli, 1985a; Denham, 2015; Moorwood, 2002). Today, there are about 650,000 declared Aboriginal Australians, making only $2.8 \%$ of the total population of the country (ABS, 2017), while majority of classifications identifies up to 30 ethnolinguistic families with around 360 languages, comprising those already extinct and more than $90 \%$ heavily endangered living languages and dialects (Bowern, 2012; Suppl. File 1, Table 1). 
A practice of burning the primeval megafauna, designated as fire-stick farming and unique merely for Australia, spawned the landscapes widely known as bushlands, with meagre but retained initial floristic structure (Castelli, 1985b; Jones, 2012). They serve as a source of what bush tucker, an Australian English denomination for easily accessible plant food, such as berries, fungi, grain grasses, nuts or yams, and facilely hunted large animals for meat, like kangaroo (Macropus spp.) (Adams et al., 2018). As a consequence, the native Australian yam species, such as Amorphophallus galbra $\mathrm{F}$. M. Bailey, A. paeonïfolius (Dennst.) Nicolson, Cayratia trifolia (L.) Domin, Dioscorea transversa R. Br., D. villosa L., Ipomoea aquatica Forssk., I. costata F. Muel. ex Benth., I. diamantinensis J. M. Black, Portulaca bicolor F. Muell., Typhonium liliifolium F. Muel. ex Schott and Vigna lanceolata Benth., had found a multitude of new ambiences and became staple food for tens of millennia.

Every individual element of the Australian Aboriginal culture, including farming, revolves in a perfect symphony with the others around a kind of cosmic maypole called Dreamtime or, in Western Arremte language, Altierizinga, a philosophical and religious concept, meaning eternal, everywhen, out of time, time before or uncreated (Castelli, 2002). In a remote epoch, humanoid and supreme progenitor beings, the Kundingas, descended from the sky and settled in the Great Sandy Desert near the great rocky complex of Uluru or Ayers Rock (Castelli \& Alessandrini, 1984). During their sojourn and before their definite departure, they dreamed the complete Australian territory, searching for wells and other goods marked the paths of these travels, labelled as dreaming tracks or songlines (Castelli, 1987). By esteeming life, Dreamtime could be considered akin to Christianity (Rainbow Spirit Elders, 2007).

The timeless rock paintings and the mythology of the Aboriginal Australians portray the Kundingas as shape-shifting, with the form of yam as one of the most prominent (Veth et al., 2018; Suppl. File 1, Fig. 2). One of the most recurring themes in these tales is a slaughter between Ngardilpi or Big Yam people and Wapurtarli or Little Yam people, ending with peace and with each battlefield becoming a sacred place for yam ceremonies restricted for the initiated males (Spencer, 2010). It is exactly the latter yam, $V$. Lanceolata, and its place in the Australian Aboriginal culture we are devoting this amalgam of plant and human sciences.

\section{I come from a land down under}

Bearing several names in English, such as bush carrot, Maloga bean, native bean, parsnip bean, pencil yam or small yam (NPGS, 2018), V. Lanceolata belong to the section Vigna, together with around twenty more, including the economically important $V$. Luteola (Jacq.) Benth., $V$. manina (Burm.) Merr. and $V$. subterranea (L.) Verdc., as well as to the subgenus Vigna of the genus Vigna Savi of the tribe Phaseoleae Bronn ex DC. (Delgado-Salinas et al.,
2011). The infraspecific variability of $V$. Lanceolata has been largely recognised, with several analyses of its qualitative and quantitative traits describing the species as highly heterogeneous (Lawn \& Holland, 2003) and encompassing a certain number of morphotype groups, like those labelled as Central or Silverleaf (Holland \& Butcher, 2012). The previously proposed varieties angusta E. Pritz, filiformis Benth., lanceolata Benth. and Latifolia C. T. White have been abandoned by all current classifications as insufficiently precise, leaving the issue of updating the genetic and phenotypic convolutedness of the species open (Nubankoh et al., 2015). The chromosome number of $V$. Lanceolata is identical to that of its closest botanical relatives, $x=11$ or $2 n=22$ (Pasquet \& Vanderborght, 1999).

During the transition of one half of 19th century into another, the existence of $V$. Lanceolata was publicly announced to the worldwide plant science community for the first time (Mitchell, 1848). George Bentham, a British botanist, gave a detailed description of its aboveground organs, such as smooth shoots, elongated stipules, trifoliolate leaves with whole and spear-like leaflets of various widths, slightly lobed in the basal region, and notable aerial flowers on long peduncles and of more or less intense yellow corolla colour (Fig. 1, second and third row). The growth habit of $V$. Lanceolata is dominantly prostrate, with long, creeping or vining stems (Fig. 1, first row), and colloquially regarded as a bush. The underground organs of $V$. Lanceolata are a tap root and relatively short, elongated and moderately thin tuberous formations (Fig. 1, first row), which may produce rhizomes (Saravana Kumar et al., 2012) and which associate the plant with yams, in general, as well as with pencil, carrot (Daucus carota L.) and parsnip (Pastinaca sativa L.), in particular. The propagation of the species is quite complex, encompassing both vegetative and generative mechanisms. The first is akin to other plants with transformed storage rhizomes, while the seeds, developed by the pollination of chasmogamous flowers and shattered by the clustered and successively maturing dehiscent pods (Fig. 1, fourth row), is responsible for the second one. Apart from these aerial inflorescences, $V$. lanceolata is characterised by amphicarpic flowers, pods and seeds (Figure 1, third row). This represents a kind of genetically-controlled adaptation to persist unfavourable environmental conditions (Lawn \& Bielig, 2016).

The genus Vigna is represented in the flora of Australia with five species, namely $V$. Lanceolata, $V$. Luteola, $V$. marina, $V$. radiata (L.) R. Wilczek and $V$. vexillata (L.) A. Rich. (Lawn \& Watkinson, 2002), of which the furst one is endemic solely to Australia. The Global Biodiversity Information Facility (GBIF) treasures precious, thorough and updating information about the ecogeography of $V$. lanceolata. This species is present in the wild floras of all the states and territories of the Commonwealth of Australia, except the Australian Capital Territory and Tasmania (Fig. 2). 


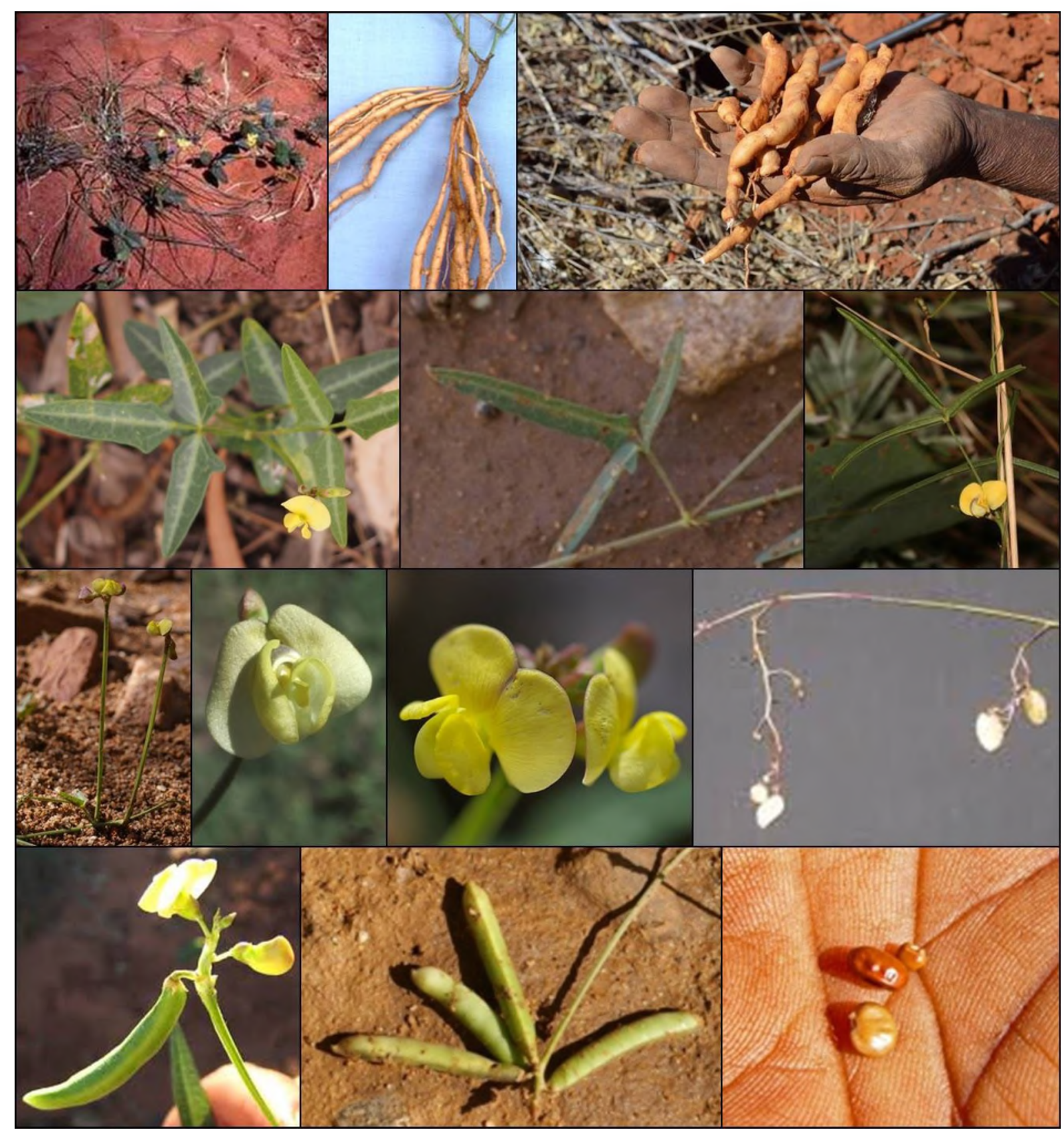

Figure 1. Some morphological features of Vigna lanceolata: (from left to right and from top to bottom) creeping or trailing growth habit typical for isolated plants; tap root and rhizomes; harvested rhizomes; broad leaflets; medium-width leaflets; narrow leaflets; long and upright peduncles; less intense coloured aerial flowers; more intense coloured aerial flowers; colourless amphicarpic flowers; an immature aerial pod; aerial pods assembled in an infructescence; aerial seeds

Of the total number of 1811 catalogued accessions of $V$. lanceolata in GBIF, almost $91 \%$, that is, 1646 , come from the Northern Territory, followed by 83 from Western Australia, 52 from New South Wales, 13 from Queensland, 10 from South Australia and one from Victoria. The single remaining accession in the GBIF database is the only one outside of the Australian state borders, located in Old Mawata of the Papua New Guinea mainland, with the monsoon climate type (GBIF, 2018).
The largest portion of the recorded specimens of $V$. Lanceolata are kept in the Northern Territory flora atlas in Palmerston, while the remainder is kept in the Western Australian Herbarium in Kensington, the National Herbarium of New South Wales in Sydney, the Australian National Herbarium in Canberra, the Department for Environment and Water in Adelaide, the Kew Gardens in London, UK, the Atlas of the New South Wales Wildlife in Sydney and the Harvard University Herbaria in Cambridge, USA (Discover Life, 


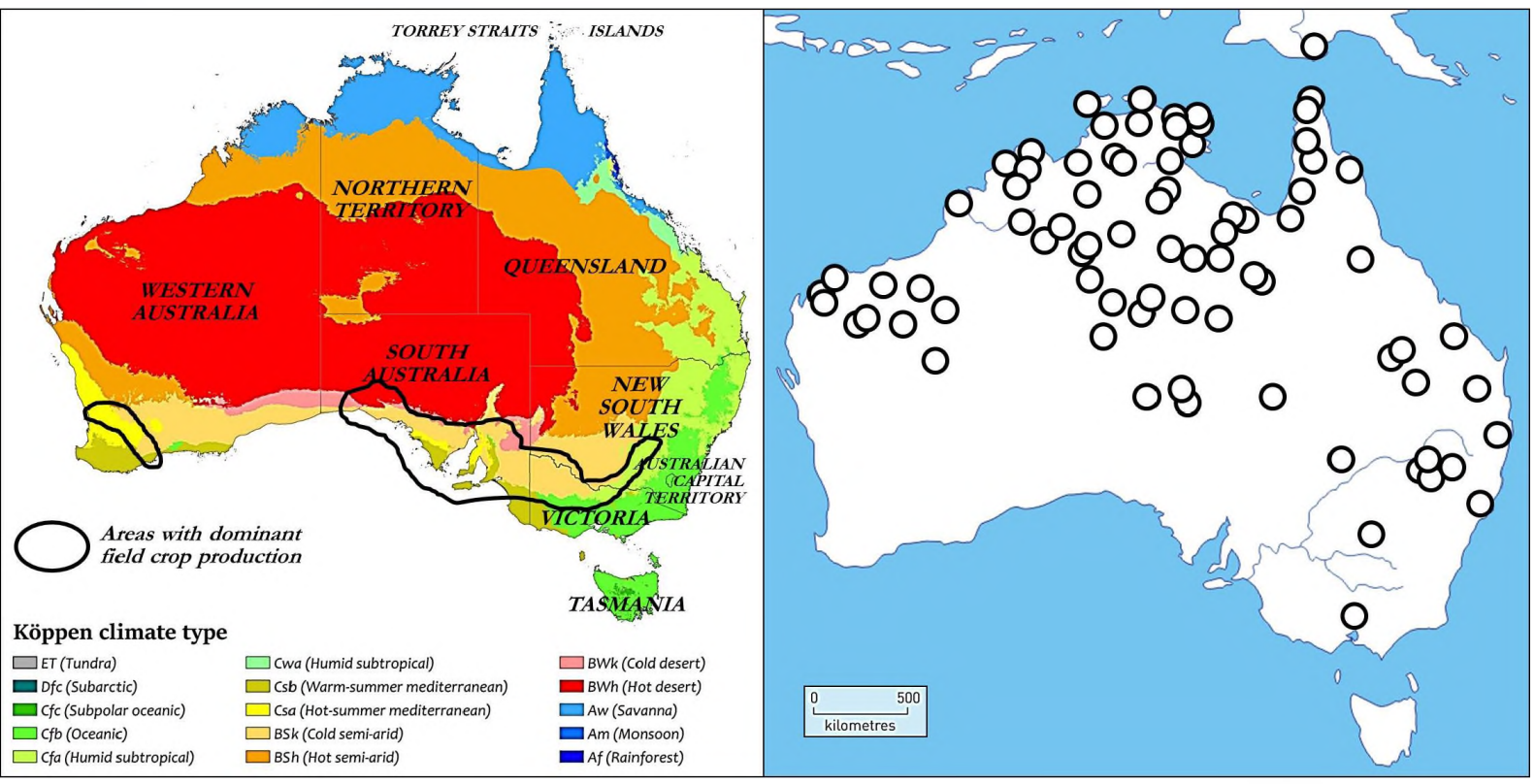

Figure 2. Two comparative maps of the continent of Australia, displaying (left) the distribution of the Koppen climate types across the Australian states, territories and islands, designating the areas with dominant field crop production, and (right) the spatial dispersal of Vignalanceolatu, with each circle denoting either one or several geographically close of 1811 catalogued populations, with a single exception of the location recorded in the southernmost mainland of Papua New Guinea, with a monsoon climate (Discover Life, 2018; GBIF, 2018)

2018). The riddle of a striking adaptability of $V^{\text {. }}$ lanceolatit to an ample range of climates becomes even more taunting by the communications about its appreciable ecological compliance to extremely different cnvironments. They cover both natural habitats and man-shaped landscapes, such as close to streams, rivers, creeks, channels, drains, lagoons, gulfs and coasts, in rock holes, next to mines, such as in Pine Creek in the Northern Territory, on sandy flats, downs and hills, in bushlands, grasslands, like the Brigalow Belt in Queensland, and rainforests, near farms and paddocks and along roadsides, highways, railways, airstrips and ports (Lawn, 2015). One of the assumed explanations for the scarcity of $V$. Lameolata in the southern portion of Australia is intensive field crop production and sheep overgrazing during past two centuries (Cahir et al., 2018).

\section{...Flesh, antidotes, \\ Old rites with flames, \\ All lines and dots, Myriad names...}

As in other similar hunter-gatherer societies worldwicte, it is the women, who have been acting as the cardinal lore-keepers of yams biogeography (Atchison \& Head, 2012), as well as the most experienced searchers for the yellow flowers of $V$. Lanceoiata and harvesters of its tubers (Suppl. File 1, Fig. 3). Digging for this and other yams with sticks of various materials, like bone, wood or, since short while ago, metal, is quite comparable to ploughing, in terms of turning over soil laycrs and cnhancing its acration, bettering its watcr regime and nutrient flow and improving microbial activity, all resulting in higher and tuber yields during next seasons (Butlin, 1993). The underground fibrous fruits, having the taste of Ipomoea batatas (L.) Lam., are eaten raw or baked, according to one of recipes of the seemingly world's oldest cuisines, within a densely handmade heap of earth upon which the fire is lit (Suppl. File 1, Fig. 4) and until they lose enough water to become firmer and still desirably juicy (Dyson, 2006).

Since the plants of $V$. Lanceoiala grow within wild flora, we may merely makc a rather unprecise estimation of its tuber yicld. (On the premises of a medium-sized taw tuber and its chemical composition, with $770 \mathrm{~g} \mathrm{~kg}^{1}$ of water, $175 \mathrm{~g} \mathrm{~kg}^{1}$ of crude carbohydrates and $28 \mathrm{~g} \mathrm{~kg}^{1}$ of crude protein (Maconochie, 1985), the average raw tuber mass varies between $110 \mathrm{~g}$ and $120 \mathrm{~g}$ or from $0.9 \mathrm{~kg}$ plant ${ }^{-1}$ to $1.5 \mathrm{~kg}$ plant ${ }^{-1}$. These values may be stimulating for the pioneering studies in the $l$. ianceoiata production potential if properly cultivated, even if they may be several times lower when compared to economically much more significant yam crops native to other continents and with advanced agronomy, such as Dioscorea alata I. (Srivastava ct al., 2012). During baking, the watcr content reduces approximately by half, similarly to other yams (Adelaja et al., 2010). Cnlike the products introduced from Europe and North America, such as bread, cakes or pasta that seriously trigger cardiovascular diseases and diabetes among Aboriginal Australians, $V$. lancelata and other ingredients of their traditional diets have 

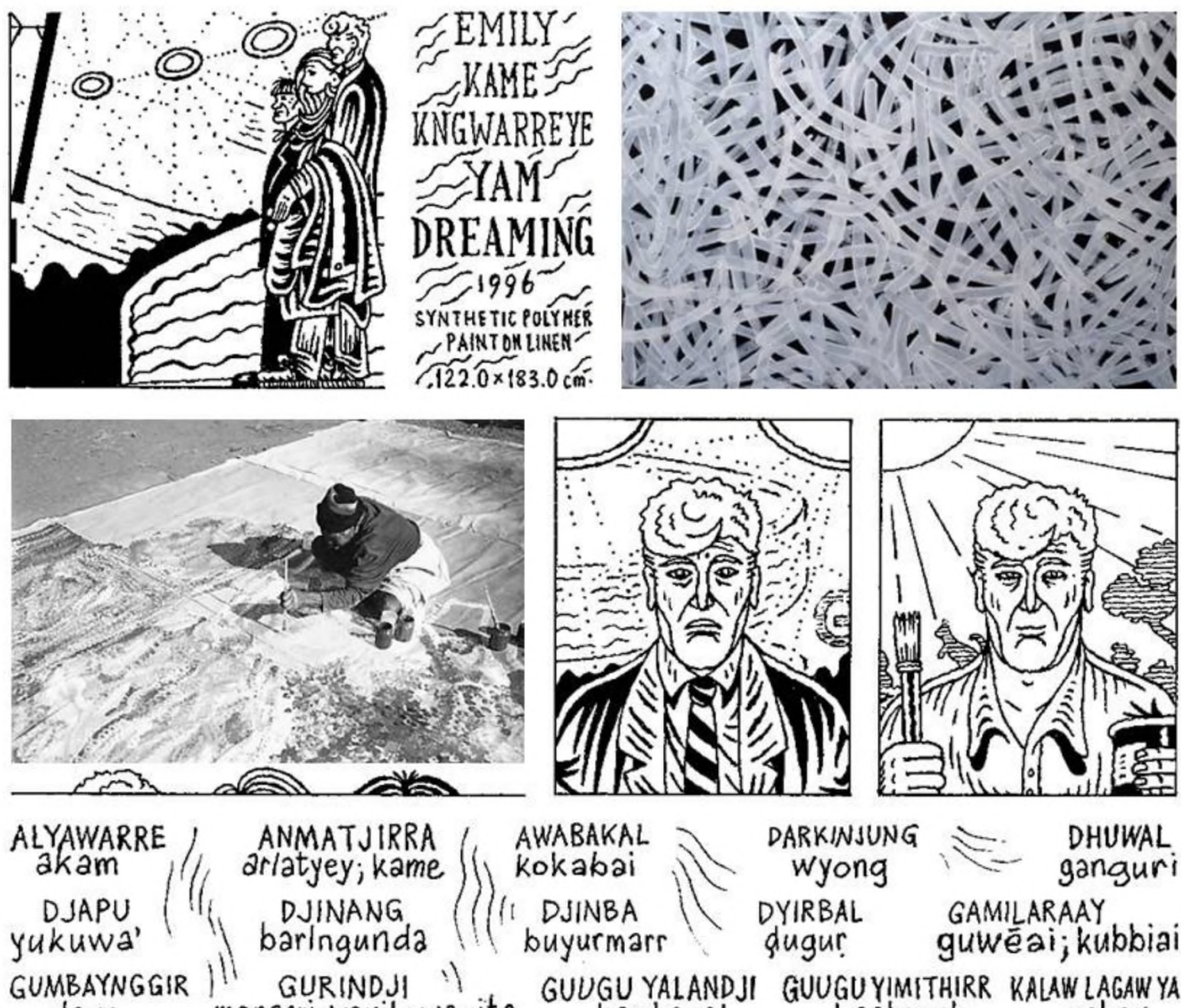

\section{AWABAKAL Kokabai \\ DJINBA} buyurmars

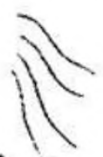
DARKINJUNG Wyong

DYIRBAL gugur

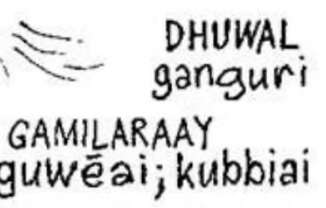
da:m

GURINDJI ') GUUGU YALANDJI GUUGUYIMITHIRR KALAW LAGAW YA manaari;wayit; wayita bambayal baabuunh gabau LOWER ARRERNTE alatyeye

$$
\text { (ii) MALNGIN }
$$

\section{MARTUTHUNIRA mada \\ NYANGUMARTA kanyjamarra \\ UPPER ARRERNTE arlatyeye}

UPPER ARRERNTE (WESTERN) latyeye; latjiya

WARLMANPA Wabidi

WARRONGO ganyo

\section{MAYI-KULAN Kowar \\ PILINARA wanymirra

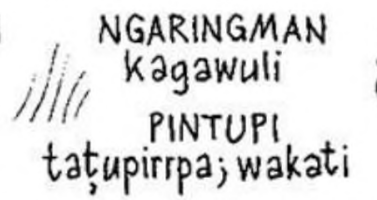

MARTU WANGKA Kanyjamarra

$$
\begin{gathered}
\text { NGARLUMA } \\
\text { mardirra }
\end{gathered}
$$

RITHARNGU ganguri; mawunu UPPER,ARRERNTE (CENTRAL)) UPPER, ARRERNTE (EASTERN) árlatyeye WAGAYA MEnaji

WALMAJARRI WALMAJARRI (EASTERN) WARLPIRI

$$
\text { jirrirlpaja; kujuntu juWa }
$$

WARRNAMBOOL japirda;ngalajiyi; wajarakijwapirti; yumurnunju tjirang

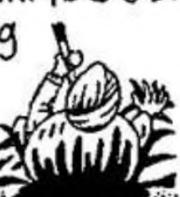

Figure 3. Common names denoting Vigna lanceolata in some of the Australian Aboriginal languages and dialects (Mikić, 2018), with the names of languages and dialects in capital letters and the names in lowercase, set in an imaginary two-panel story of the comic character Martin Mystère; first panel gives the names in the Pama-Nyungan languages (continued on the next page) 


BARDI
narRga
ENINDHILYAGWA
MWARntakirriyarra
GARAWA (WESTERN)
Mili

IWAIDJA

Wangkartuk

KAYARDILD

jiwi; thadawa

KWINI

WegU

MANYALLALUK MAYALI
KaTrEMUDYi

MURRINH-PATHA

WAGIMAN

Johyin; yoyin

WORRORRAN

inkalba; karnmangku; wungunimbim liindyi

KIJA ngawoonyji LARAGIYA wila Warkuja NGARINYIN alamer WAMBAYA jigama thalam; WaWa

BURARRA jaypurlga;mun-garra

GAAGUDJU djugu-djoogu;moornarn GIIMBIYU GOONIYANDI

\section{JAMINJUNG $\approx$
gagaWOOli $=$}

MARRANJ
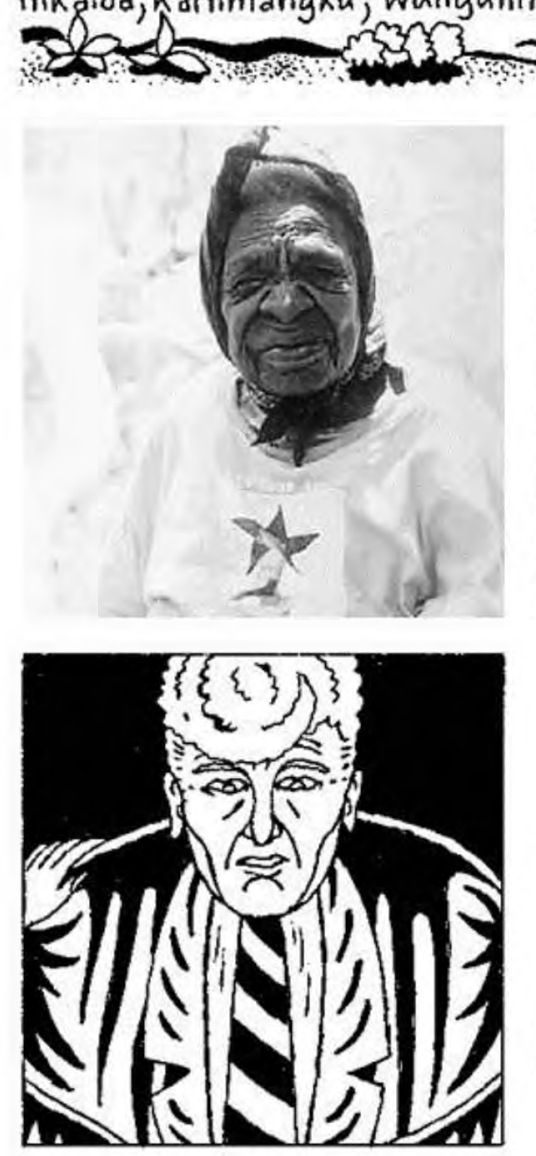
WUNAMBAL ngulwana

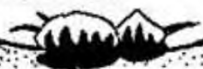
birla

KUNE

DAMIN

kurrikurrijpi $m$ ! ii; wiiti $m ! i j$ GAMBERRE GARAWA
Wanggalu W kabala GUNDJEIHMI garrbarda

GURAGONE djunja;wartbirritji JINGULU karrangayimi KUNWINJKU karrbarda

\section{MALAK-MALAK} yeyeynin burrkU MATNGELE belerr; derrngey; mal

MAUNG ariamun MIRIWOONG wanmalang

\section{NUNGGUBUYU TIWI}

(i) warda marntinga; murani; murrunkawini

WARDAMAN mordon; 'Wayida
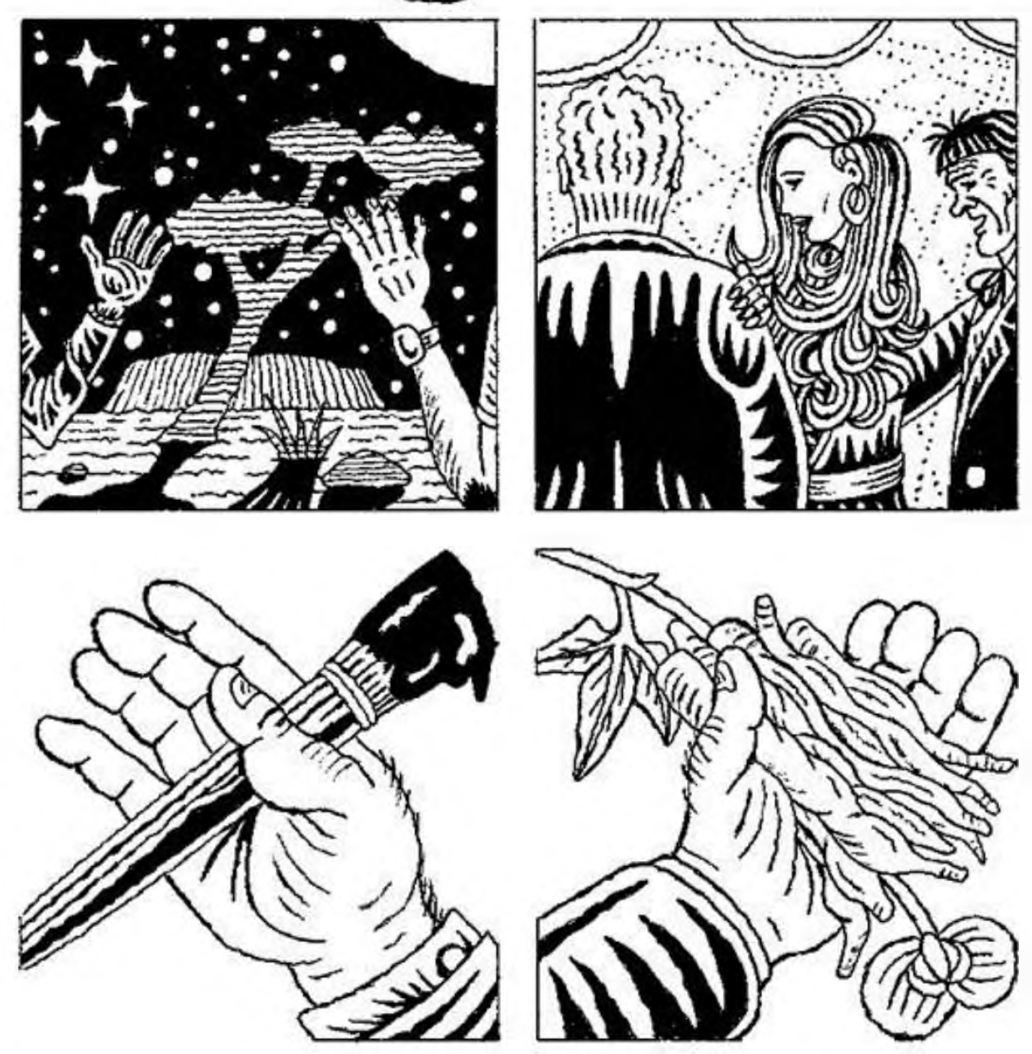

Figure 3. (continued) The second panel lists the names denoting Vigna lanceolata in the non-Pama-Nyungan languages; both panels include (second panel, middle row, first from left) the genuine photograph portrait of the most famous Australian Aboriginal artist, Emily Kame Kngwarreye, (first panel, middle row, first from left) the photograph of Ms. Kngwarreye creating in the field and (first panel, top row, third from left) her painting Yam Dreaming 
beneficial effects due to a lower glycaemic index with slower release and low fat proportion (Williams, 2012). If prepared as powders or tonics, they may also be potent anti-ageing, anti-inflammatory, anti-hypertensive, anti-neurodegenerative, antioxidant, antithrombic, anxiolytic, cardioprotective, cholesterol-lowering and immunomodulatory agents (Williams, 2013).

A phytolinguistic quest for the vernacular names denoting $V$. Lanceolata in the available dictionaries and other lexical resources of nearly every extinct and living Australian Aboriginal languages and dialects identified more than 100 words belonging to 84 spoken languages (Mikić, 2018; Fig.3 and Suppl. File 1, Fig. 5) and one sign language (Iltyem-iltyem, 2018; Suppl. File 1, Fig. 6, and Suppl. File 2) of each ethnolinguistic family. The overlapping between the spatial distribution of the species' populations (Fig. 2, right) and their geographic location of the languages with attested names referring to V. Lanceolata (Suppl. File 1, Fig. 5) may be deemed verily outstanding (AuSIL, 2018). The morphological variability of the compiled popular names is incomparably wider in comparison to other ethnolinguistic families of the world, primarily due to an incomparably longer development. Lexicologically, we may only comment sporadic cases of the congruence between morphology and semantics of the vernacular names referring to $V$. lanceolata in genealogically close languages and dialects, such as in Gurindji, Kunwinjku, Upper Arrernte or Wumbala. There are also examples of the lexical exchange between the languages of different families, like Pilinara and Wardaman.

The etymology of popular names linked to this legume is notably fragmented, but is able to suggest possible roots, such as the Proto-Arandic *manaatyi and its cognates in Wagaya and Waramungu (Koch, 2004) and the Proto-Ngarna *jika (McConvell \& Laughren, 2004), within the Pama-Nyungan languages. The Aboriginal Australians make distinction among the morphotypes of $V$. lanceolata and have distinct name to denote those with extremely narrow leaflets, as seen in the Alyawarre atnwelam and the Warlpiri kupunturu. The vernacular names denoting the species also exist in the Australian Aboriginal English, with am, the Papuan languages Meriam, with lewer, and Nambu, with taita, and the creoles, such as Australian Kriol, with yarma, and Torres Strait Creole, with yam.

\section{Carpe diyam!}

Seize the yam! We may say that this enthusiastic slogan finally has its real and optimistic grounds. During the last decade, there has been made a rapid move forward in domesticating $V$. lanceolata, exceptionally likely the first ever done in the entire history of this plant in the continental mass of the Sahul Shelf. The
Australian legume research community began to recognise the remarkable potential of $V$. lanceolata, which has already been apprehended for an indefinite time in the past. Thus, today, the knowledge accumulated for tens of millennia and passed from one to another generation of the Aboriginal Australians is inspiring the spurring actions by the Australian governmental institutions in the in situ preservation and ex situ conservation, accompanied with establishing passport databases, extending ecogeographical notes, formulating descriptors and introducing diversity arrays technology (DArT) molecular marker analyses, as in the case of the recent field examinations in the Pilbara region of Western Australia (Lawn \& Cottrell, 2018).

In parallel, we are witnessing the genesis of the pioneering efforts in breeding $V$. lanceolata, with controlled hybridisation and developing hybrid generations, articulating the ideotypes of future cultivars, encompassing annual and perennial genotypes, amphicarpic and aerial seed morphotypes and uses in human consumption, pretty similar to Jerusalem artichoke (Heliantbus tuberosus L.) (Terzić et al., 2012) and animal feeding (Lawn et al., 2016). Such work is based upon thorough studies on the mutual correlations among physiological, morphological and economically important parameters, with emphasis on the duration of growing season, grain yield components, tuber yield and chemical composition (Lawn \& Rebetzke 2006).

Apart from the scientific advances relating to $V$. lanceolata, we are also privileged to observe a true resurrection of the Australian Aboriginal art, conceived by and handed over to new generations by the immortal Emily Kame Kngwarreye (Fig. 3), which attracts not only the world-wide recognised connoisseurs, but also the amateurs, to a sacred well of the finest native painting, embedded in the very heart of the Australia continent (McCulloch \& McCulloch Child, 2008).

\section{$* * *$ \\ ...Here where they have memorial park. \\ One time lubras dug for yams...}

(From the poem Then and Now by Oodgeroo Noonuccal; Noonuccal \& Walker, 1992)

\section{kagawnil. \\ ...I'm really old people now. I want to go bome to}

(The last wish of the 90-year Ngaringman saltwater man Big Mick Kangkinang, Robin \& Heinsohn, 2009) 


\section{References}

ABS (2017). Aboriginal and Torres Strait Islander Population. Canberra: Australian Bureau of Statistics.

Adelaja, A. O., Asemota, O. S., \& Oshiafi, I. K. (2010). Experimental determination of the moisture content pattern in yam during drying. Joumal of Applied Sciences Research, 6, 1171-1181.

Adams, V. M., Douglas, M. M., Jackson, S. E., Scheepers, K., Kool, J. T., \& Setterfield, S. A. (2018). Conserving biodiversity and Indigenous bush tucker: Practical application of the strategic foresight framework to invasive alien species management planning. Conservation Letters, 11, e12441.

AuSIL (2018). Dictionaries. Darwin - Alice Springs - Katherine - Kupang: The Australian Society for Indigenous Languages.

Atchison, J., \& Head, L. (2012). Yam landscapes: The biogeography and social life of Australian 'Dioscorea'. Antefact: the Joumal of the Anbaeological and Antbropological Soixety of Vitoria, 35, 59

Bae, C. J., Douka, K., \& Petraglia, M. D. (2017). On the origin of modem humans: Asian perspectives. Science, 358, eaai9067.

Bowern, C. (2012). Master List of Australian Languages (Vol.1.2). New Haven: Yale University.

Butlin, N. G. (1993). Economics and the Dreamtime: A Hypotbetical History. Melbourne: Cambridge University Press.

Cahir, F., Clark, I., \& Clarke, P. (2018) Aboniginal Biocultunal Knowledge in Southeastern Australia: Perspectives of Early Colonists. Clayton: CSIRO Publishing.

Castelli, A. (1985a). Mysterions Australia. Milan: Daim Press.

Castelli, A. (1985b). At the Borders of the Reality. Milan: Daim Press.

Castelli, A. (1987). Ayers Rock. Milan: Daim Press.

Castelli, A. (2002). Altierjinga. Milan: Sergio Bonelli Editore.

Castell, A, \& Alessandrini, G. (1984). The Children of the Dream. Milan: Daim Press.

Castelli, A., \& Di Cesare V. (1996). The Paradise of the Anthropologists. Milan: Sergio Bonelli Editore.

Delgado - Salinas, A., Thulin, M., Pasquet, R, Weeden, N., \& Lavin, M. (2011). Vigna (Leguminosae) sensu lato: the names and identities of the American segregate genera. American Joumal of Botamy, 98, 1694 1715.

Denham, W. W. (2015). Alyawarra kinship, infant carrying, and alloparenting. Mathematical Anthropology and Culture Theory, 8, 640994nk

Discover Life (2018). Vigna lancelata Benth. In: Pickering, J. (ed) Discover Iiffe. Athens: University of Georgia.

Dyson, L. E. (2006). Indigenous Australian cookery, past and present. Joumal of Austratian Studies, 30, 5-18.

GBIF (2018). Vigna lanceolata Benth. Copenhagen: Global Biodiversity Information Facility.

Holland, A. E., \& Butcher, R (2016). Vigna triodiophila (Fabaceae. Phaseoleae), a new conservation-listed species from the Pilbara, Western Australia. Nintsia, 27, 77-83.

Iltyem-iltyem (2018). Anmatyerr. In: Carew, M. (ed) Iltyem-iltyem Austratian Indigenous Sign Lanouages. Batchelor: Batchelor Institute of Indigenous Tertiary Education.

Jones, R. (2012). Fire-stick farming. Fine Ecology, 8, 3-8.

Koch, H. (2004). The Arandic subgroup of Australian languages. In: In: Bowern, C. Koch, $\mathrm{H}$ (eds) Australian L anguages: Classification and the Comparative Method. Amsterdam: John Benjamins B. V., 127-150.

Lawn, R. J. (2015). The Australian Vigna species: A case study in the collection and conservation of crop wild relatives. In: Redden, R., Yadav, S. S., Maxted, N., Dulloo, M. E., Guarino, L., Smith, P. (eds) Crop Wild Relatives and Climate Change. Hoboken: John Wiley \& Sons, 318-335.

Iawn, R. J., \& Bielig, L. M. (2016). Expression of amphicarpy in Vigna lanceolata morphotypes and their hybrids and implications for cultivar development. Crop and Pasture Science, 67, 978-987.

Lawn, R. J., \& Cottrell, A. (2018). Distribution, habitat, morphological diversity and genetic interrelations of native Vigna in the Pilbara, Western Australia. Crop and Pasture Science, 69, 985-998.

Lawn, R. J., \& Holland, A. E. (2003). Variation in the Vigna lanceolata complex for traits of taxonomic, adaptive or agronomic interest. Australian Joumal of Botany, 51, 295-307.
Lawn, R. J., \& Rebetzke, G. J. (2006). Variation among Australian accessions of the wild mungbean (Vigna radiata ssp. sublobata) for traits of agronomic, adaptive, or taxonomic interest. Crop and Pasture Science, 57, 119-132.

Lawn, R. J., \& Watkinson, A. R. (2002). Habitats, morphological diversity, and distribution of the genus Vigna Savi in Australia. Crop and Pasture Srience, 53, 1305-1316.

Lawn, R. J., Vu, H. T., Bielig, L. M., \& Kilian, A. (2016). Genetic compatibility among morphotypes of Vigna lanceolata and implications for breeding improved cultivars. Crop and Pasture Science, 67, 739-750.

Maconochie, J. R. (1985). Plants from the Australian arid zone - An undeveloped potential. In: Wickens, G.E.. Field, D. V., Goodin, J. R. (eds) Plants for Arid L ands. London: Unwin Hyman.

McConvell, P., \& Laughren, M. (2004). The Ngumpin-Yapa subgroup. In: In: Bowem, C, Koch, H. (eds) Australian Languages: Classification and the Comparative Method. Ansterdam: John Benjamins B. V., 151178.

McCulloch, S., \& McCulloch Child, E. (2008). Mralloch's Contemporay Aboriginal Ant: The Complete Guide. Balnarring: McCulloch \& McCulloch Australian Art Books.

Mikić, A. (2011). Can we reconstruct the most ancient words for pea (Pisum sativum)? Pisum Genetics, 43, 36-42.

Mikić, A. (2018). Lexicon of Pulse Crops. Boca Raton: CRC Press

Mitchell, T. L. (1848). Joumal of an Expedition into the Interior of Tropical Australia, in Searb of a Route from Sydney to the Gulf of Carpentaria. London: Longman, Brown, Green and Longmans.

Moorwood, M. J. (2003). Visions from the Past. The Archaeology of Austratian Aboriginal Ant. Crows Nest: Allen \& Unwin.

Noonucal, O., \& Walker, K. (1992). The Dawn is at Hand: Selected Poems. London: Marion Boyars.

NPGS (2018). National Plant Germplasm System (NPGS). Germplasm Resources Information Network. Washington - Beltsville: United States Department of Agriculture, Agricultural Research Service.

Nubankoh, P., Pimtong, S., Somta, P., Dachapak, S. \& Srinives, P. (2015). Genetic diversity and population structure of pencil yam (Vigna lancelata) (Phaseoleae, Fabaceae), a wild herbaceous legume endernic to Australia, revealed by microsatellite markers. Botamy, 93, 183-191.

O'Connell, J. F., Allen, J., Williams, M. A., Williams, A. N., Turney, C. S., Spooner, N. A., Kamminga, J., Brown, G., \& Cooper, A. (2018). When did Homo sapiens first reach Southeast Asia and Sahul? Procedings of the National Academy of Saiences, 115, 8482-8490.

Pasquet, R S., \& Vanderborght, T. (1999). Isozyme polymorphism in some yellow-and blue-flowered Vigna species complexes (Fabaceae, Phaseoleae). Plant Systematics and Evolution, 215, 1-21.

Rainbow Spirit Elders (2007). Rainbon Spivit Theology: Tonards an Australian Aboriginal Theology. Adelaide: ATF Press.

Robin, L., \& Heinsohn, R. (2009) Boom \& Bust: Bird Stories for a Dy Country. Clayton: CSIRO Publishing:

Saravana Kumar, P. , Lawn, R. J., \& Bielig, L. M. (2012). Comparative studies on reproductive structures in four amphicarpic tropical Phaseoleae legumes. Crop and Pasture Science, 63, 570-581.

Spencer, B. (2010). Native Tribes of the Nontbern Territory of Australia. New York: Cambridge University Press.

Srivastava, A. K, Gaiser, T., Paeth, H, \& Ewert, F. (2012). The impact of climate change on yam (Diuscorea alata) yield in the savanna zone of West Africa. Agriculture, Ecosystems er Emiroment, 153, 57-64.

Terzić, S., Atlagić, J., Maksimović, I., Zeremski, T., Zorić, M., Miklič, V., \& Balalić, I. (2012). Genetic variability for concentrations of essential elements in tubers and leaves of Jerusalem artichoke (Helianthus tuberosus L.). Srientia Honticulturae, 136, 135-144.

Veth, P., Myers, C., Heaney, P., \& Ouzman, S. (2018). Plants before farming: The deep history of plant-1 1se and representation in the rock art of Australia's Kimberley region. Quatemany International, 489, 2645.

Willians, C. J. (2012). Medicinal Plants in Australia. Volume 3. Plants, Potions and Poisons. Kenthurst: Rosenberg Publishing.

Williams, C. J. (2013). Medicnal Plants in Australia. Volume 4. An Antipodean Apothecary. Kenthurst: Rosenberg Publishing. 


\section{Vigna lanceolata u ratarenju vatrom i australijskoj urođeničkoj kulturi}

\section{Alfredo Castelli · Aleksandar Mikić}

Sažetak: Amfikarpna i krtolasta jamolika mahunarka Vigna Lanceolata Benth., endemska u Australiji, ima izvanredni značaj u osobenom vidu ratarenja i celokupnoj kulturi urođeničkih naroda tokom desetina milenijuma. Naš pregled, stapajući prirodne i društvene nauke i umetnost, daje kratki i činjenicama bogati prikaz ove vrste, razmatrajući njenu sistematiku i morfologiju, opisujući njena hranljiva i lekovita svojstva, istražujući njenu ekogeografiju, s izuzetnim obiljem populacija u severnim oblastima kontinenta, razjašnjavajući njeno široko rasprostiranje kao posledicu prethodne upotrebe vatre $u$ menjanju životne sredine i načine njenog prepoznavanja u divljini, ubiranja i pripreme $u$ ljudskoj ishrani, oslikavajući njenu ulogu u australijskoj urođeničkoj umetnosti, kao jednog od najsvetijih predmeta religije Sanjanja, dajući njena narodna imena na 85 izumrlih i živih australijskih urođeničkih jezika i zaključujući otvaranjem novih horizonata njenog istraživanja, putem nedavno začetih programa biodiverziteta i oplemenjivanja. Ključne reči: Aboridžini, Australija, ratarenje vatrom, umetnost, Vigna lanceolata 